\author{
MONIKA ADAMSKA-STAROŃ \\ Uniwersytet Humanistyczno-Przyrodniczy im. Jana Dtugosza \\ $w$ Częstochowie
}

\title{
SPOTKANIE \\ Z WYBRANYMI TEKSTAMI KULTURY POPULARNEJ. W STRONĘ RELACYJNEGO BYCIA W ŚWIECIE
}

\begin{abstract}
Aвstract. Adamska-Staroń Monika, Spotkanie z wybranymi tekstami kultury popularnej. W stronę relacyjnego bycia w świecie [Meeting with Selected Texts of Popular Culture. Towards Relational Being in the World]. Studia Edukacyjne nr 50, 2018, Poznań 2018, pp. 331-349. Adam Mickiewicz University Press. ISSN 1233-6688. DOI: 10.14746/se.2018.50.22
\end{abstract}

This text aims to familiarize the reader with a certain way of thinking about the category of meeting, selected pedagogical consequences that can take place as a result of young people's encounter with texts of popular culture, especially with rock music and film, and to include the recipient in the discussion of the presented issue. The text consists of three parts. The first part is an introduction to the range of questions and treats the meeting as a pedagogical category. The second section focuses on the phenomenon of meeting texts of popular culture, more specifically rock and film narratives, while the third, summarizing part describes the meeting of young people with rock narratives on the basis of the results of the author's own research.

Key words: meeting, education, popular culture, rock music

\section{Wstęp}

Zainteresowanie kwestią spotkania jako kategorią pedagogiczną, wydarzeniem o znaczeniu edukacyjnym, inspirowanie dzieci i młodzież do pełnego udziału w spotkaniu z drugim człowiekiem, opartym na dialogu, zaangażowaniu, autentyczności jest działaniem ważnym i potrzebnym, nieocenionym $\mathrm{w}$ procesie edukacji, $\mathrm{w}$ procesie uczenia się akceptacji Innego, różnorodności, w zrozumieniu drugiego człowieka. O zasadności rozbudzania wrażliwości na różnicę, na inność, poszukiwania nowych sposobów, metod współpracy, zachęcania do relacyjnego bycia w świecie, przemawiają zarówno obserwa- 
cje współczesnego człowieka, społeczeństwa, zwiększająca się różnorodność świata, konflikty, które mają swoje źródło w niezrozumieniu odmienności, ale i naukowe badania, teoretyczne rozważania koncentrujące się wokół człowieka, społeczeństwa, kultury, w tym edukacji ${ }^{1}$.

Świat, w którym żyjemy stanowi mozaikę wielu jakości, między innymi wartości, sposobów myślenia, działania, wielu propozycji edukowania (wychowania i kształcenia), sposobów bycia w świecie. Mnogość ta może powodować, i niejednokrotnie powoduje, ludzką wobec niej bezradność. Do marginalnych nie zalicza się konsumpcyjny sposób bycia, chęć posiadania, czy instrumentalizacja ludzkich relacji. Tendencja do "mieć” jest czynnikiem dehumanizującym człowieka, ujawnia aprobatę przedmiotowego traktowania drugiego/innego, porzucenie rozmowy na rzecz "mówienia”. Szczególnie w wielkich miastach, gdzie ludzie doświadczają samotności, odczuwają tęsknotę za drugim człowiekiem, jednocześnie (z różnych powodów) włączają opór przed bliskością, wspólnotą - prawdziwym spotkaniem². Etyczną konieczność zbliżenia się, otwarcia na drugiego człowieka postulowali między innymi filozofowie dialogu i spotkania, już na początku XX wieku, jak na przykład Martin Buber, Emmanuel Levinas, Józef Tischner, czy Janusz Tarnowski. Idea dialogu, mająca swoje źródła w filozofii tych właśnie myślicieli,

${ }^{1}$ Zob. m.in.: W. Jakubowski, Edukacja w świecie kultury popularnej, Kraków 2006; Z. Melosik, Kultura popularna i tożsamość młodzieży. W niewoli władzy i wolności, Kraków 2013; W. Burszta, Kultura popularna jako wspólnota uczuciowa, Kultura Popularna, 2002, 0; A. Nalaskowski, Widnokręgi edukacji, Kraków 2002; tenże, Edukacja. Korzenie, źródta, narracje, Kraków 2017; A. Gromkowska-Melosik, Edukacja i nierówność społeczna kobiet. Studium dynamiki dostępu, Kraków 2011; taże, Elitarne szkolnictwo średnie. Między reprodukcja społeczno-kulturowa a ruchliwościa konkurencyjna, Poznań 2015; A. Cybal-Michalska, P. Wierzba (red.), Dyskursy kultury popularnej w społeczeństwie wspótczesnym, Kraków 2012; W. Strykowski, W. Skrzydlewski (red.), Media i edukacja $w$ dobie integracji, Poznań 2002; R. Derbis, Dlaczego zajmujemy sie jakościa życia, [w:] Psychologiczne konteksty jakości życia społecznego, red. R. Derbis, Częstochowa 2010; S. Kowalik, Jakość życia psychicznego, [w:] Jakość rozwoju a jakość życia, red. R. Derbis, Częstochowa 2000; S. Kowalik, Temporalne uwarunkowania jakości życia, [w:] Psychologiczne i pedagogiczne wymiary jakości życia, red. A. Bańka, R. Derbis, Częstochowa - Poznań 1994; M. Nowak-Dziemianowicz, Narracyjne możliwości pedagogiki a kryzys kultury i wychowania, http:/ / forumoswiatowe.pl/index.php/czasopismo/article/view/, [dostęp: 12.11.2018]; J. Bruner, Życie jako narracja, Kwartalnik Pedagogiczny, 1990, 4(138).

${ }^{2}$ Zob. m.in.: F. Russo, Toksyczna samotność, Świat Nauki, 2018, 3(19), s. 58-63; Ch. Victor, K. Yang, The Prevalence of Loneliness Among Adults: A Case Study of the United Kingdom, The Journal of Psychology, 2011, 146(1-2), s. 85-104; M. Luhmann, L. Hawkley, Age Differences in Loneliness From Late Adolescence to Oldest Old Age, Developmental Psychology, 2016, 50(6), s. 943-959; M. Maes i in., The Children's Loneliness Scale Factor - Structure and Construct Validity in Belgian Children, Assessment, 2015, 24(2), s. 244-251; G. Lodder i in., Adolescent Loneliness and Social Skills: Agreement and Discrepancies Between Self-, Meta-, and Peer-Evaluations, Journal of Youth and Adolescence, 2016, 45(12); Z. Dołęga, Samotność młodzieży - analiza teoretyczna i studia empiryczne, Katowice 2003; K. Wasilewska-Ostrowska, Młodzież wobec samotności w świetle badań porównawczych, Kultura i Wychowanie, 2014, 8(2). 
ujmujących egzystencję człowieka w kategorii spotkania, stanowi dla wielu inspirację do takiego bycia w świecie edukacji, nauki, czy w świecie w ogóle. Spotkanie w tym ujęciu odsłania metafizyczny wymiar ludzkiej egzystencji, sferę „pomiędzy”, stanowi punkt wyjścia do zrozumienia człowieka, różnorodności świata i samego siebie, powoduje, że człowiek doświadcza drugiego człowieka/Innego/Ty, otaczającej go rzeczywistości³. Postulowane przez przywołanych filozofów idee bliskie są również i mnie (zagadnienie spotkania ujmowanego w kontekście filozofii dialogu, spotkania jako wychowania czyniłam nieraz przedmiotem rozważań, analiz, interpretacji, badań). Dialog nie jest rozumiany tutaj jako jedna $\mathrm{z}$ tych metod nauczania i wychowania, która jest łączona $\mathrm{z}$

czynnością wyuczoną, przyswojoną, przejętą z zewnątrz, a więc nie osobistą, stanowiącą element zachowania powtarzalnego, standaryzowanego, typu technicznego, w którym minimalizowany jest własny namysł działającego człowieka, niezbędny wszak w sytuacjach wychowawczych, które są zawsze sytuacjami etycznymi ${ }^{4}$.

Chodzi tutaj o relacyjne odniesienie się do rzeczywistości, do drugiego człowieka, do samego siebie, do każdej innej istoty żywej ${ }^{5}$. Człowiek zanurzając się $\mathrm{w}$ przestrzeń relacji, zapytuje o rzeczywistość już w dialogicznej perspektywie, sam również może być zagadnięty przez inny byt - drugiego człowieka, czy też jego dzieło. Takie dialogiczne zapytywanie przejmuje go całego, staje się on wówczas uczestnikiem dziejącej się rzeczywistości ${ }^{6}$. Jednym z możliwych sposobów jej odkrywania i rozumienia mogą być spotkania $\mathrm{z}$ rockowymi, czy też filmowymi narracjami ${ }^{7}$ - tekstami wypełnia-

${ }^{3}$ Zob. M. Adamska-Staroń, Spotkanie z Innym w perspektywie idei dialogu, Pedagogika XXIII. Prace Naukowe Akademia im. Jana Długosza 2014, XXIII, s. 95-102.

${ }^{4}$ J. Rutkowiak, Wstęp, [w:] Pytanie - dialog - wychowanie, red. J. Rutkowiak, Warszawa 1992, s. 9.

${ }^{5}$ M. Buber, Ja i Ty. Wybór pism filozoficznych, przekł. J. Doktór, Warszawa 1992.

${ }^{6}$ Zob. tamże, s. 218.

${ }^{7} \mathrm{~W}$ przyjętym przeze mnie rozumieniu „narracja to dowolna wypowiedź zarówno ta "wielka" (Pan Tadeusz), jak i ta "mała” (historie z dzieciństwa opowiadane wnukom przez babcie, niepublikowane opowiadania nieznanych autorów), ustna albo też pisana" - zob. M. Nowak-Dziemianowicz, Narracyjne możliwości pedagogiki a kryzys kultury i wychowania, http://forumoswiatowe.pl/index.php/czasopismo/article/view/, s. 48, [dostęp: 12.11.2018], to sposób opisywania świata, elementów/zjawisk ten świat tworzących, relacji pomiędzy nimi, sposób konstruowania znaczeń, sposób rozumienia samego siebie, drugiego człowieka, swoich relacji ze światem - zob. M. Nowak-Dziemianowicz, Narracyjne możliwości pedagogiki, s. 35-60. Narracja ma swoją logikę przebiegu, która jest „niepodobna do struktury przyczynowo-skutkowej. Polega ona na tym, że to skutki określają znaczenie zdarzeń wcześniejszych, a nie odwrotnie, a także na tym, że proces rozumienia obejmuje w każdym momencie całość sekwencji; dopóki nie jest ona ukończona, może ulec gruntownej reinterpretacji (Schütze, 1997, s. 11-12)" zob. M. NowakDziemianowicz, Narracyjne możliwości pedagogiki. Takie znaczenie narracji w pedagogice „staje się swoistym uzasadnieniem badań rozumiejących, badań, których celem nie jest poszukiwa- 
jącymi przestrzeń kultury popularnej ${ }^{8}$, rozumianej przeze mnie jako przestrzeń możliwości - wykraczania poza to, co zastane, „przekraczania siebie ze względu na możliwości bycia", prawdziwego przeżywania, refleksji, ale i rozrywki, czy pułapek, na jakie można natrafić w jej obrębie, rozumianej jako przestrzeń, która posiada zdolność ukazywania tej sfery "pomiędzy" Nie jest ona ontologicznie monolityczna. Jest złożona, sprzeczna wewnętrznie, nieustannie „w drodze”. Coraz częściej nie jest już

postrzegana jako obszar, w którym bezmyślne masy manipulowane są przez elektroniczne media. To dyskursywna przestrzeń, w której są tworzone i negocjowane znaczenia przez jej uczestników. To także miejsce naszego uczenia się. Nie jest więc "gorsza", jest po prostu innym fragmentem kulturowej rzeczywistości ${ }^{10}$.

I właśnie o spotkaniach młodych ludzi z rockowymi oraz filmowymi narracjami, będącymi częścią kultury popularnej traktuje niniejszy artykuł. Jest on głosem w dyskusji koncentrującej się nad możliwymi sposobami „wykorzystania" tych tekstów w edukacji formalnej, nad możliwymi sposobami bycia w świecie, w którym człowiek jest usytuowany, tym samym wokół bu-

nie związków przyczynowo-skutkowych między faktami określanymi mianem zmiennych, ale jest nim poznanie, opis i rozumienie subiektywnych światów życia człowieka. Rozumienie to staje się możliwe dzięki temu, że to właśnie narracja daje nam dostęp do tego, w jaki sposób ludzie konstruują swoje światy życia, jak spostrzegają to, co się z nimi dzieje, i to, co ich otacza. Narracja zawsze ma swój kontekst kulturowy. To właśnie w określonej kulturowej przestrzeni umocowane są opowieści, to dzięki niej przybierają taki, a nie inny kształt, zawierają takie, a nie inne treści, to dzięki niej są możliwe. „Jednocześnie te same zasoby i okoliczności to swoiste ograniczenia każdej narracji. Narracja umożliwia wgląd nie tylko w opowiadaną historię - pozwala także na poznanie wszelkich okoliczności jej towarzyszących, poszerza perspektywę jednostkową o perspektywę społeczną, łączy to, co lokalne, z tym, co globalne czy uniwersalne" zob. M. Nowak-Dziemianowicz, Narracyjne możliwości pedagogiki.

${ }^{8}$ Moje myślenie o kulturze popularnej bliskie jest brytyjskiej szkole, przedstawiającej szerokie i pełne optymizmu spojrzenie na teksty kultury popularnej (na zjawiska, wydarzenia, różnego rodzaju narracje itp.). Jej zwolennicy (m.in. R. Hoggart, E.P. Thomson, R. Williams), uznali kulturę popularną za godną uwagi, zainteresowania, uczestnictwa w niej z kilku powodów: po pierwsze „wydała się ona im dużo bardziej autentyczna niż sztuka, podlegająca nieustannej instytucjonalizacji i hierarchizacji. Po drugie, kultura popularna spontanicznie wyraża tożsamość społecznych zbiorowości. Po trzecie, kultura popularna jest popularna nie dlatego, że jako widzowie czy konsumenci bezwiednie przyswajamy pewne treści, ale wręcz przeciwnie, ponieważ stawiamy im opór. Oczywiście, większość popularnych artefaktów produkowana jest na skalę przemysłową, aby przyniosły zysk. Ludzie są jednak sprytni i nieustannie kombinują, jak sprawić, aby produkt masowy miał dla nich osobisty, indywidualny wymiar. Badacze zwracają uwagę na kilka strategii, dzięki którym radzimy sobie z przemysłem kulturalnym i wciąż mamy $\mathrm{z}$ tego frajdę" - zob. S. Nowak, Kultura popularna, czyli twórcza niesubordynacja, MOCAK Forum 2012, 1(3), s. 4-5.

${ }_{9}$ M. Dudziuk, S. Szczepańska, Filmowanie jest filozofowaniem, Melee, 2009, 5, s. 6-14.

${ }^{10}$ W. Jakubowski, Wstęp. [w:] Kultura popularna -Tożsamość - Edukacja, red. D. Hejwosz, W. Jakubowski, Kraków 2010, s. 10. 
dowania lepszej jakości życia, lepszego (współ)bycia z drugim człowiekiem, budowania swojej tożsamości ${ }^{11}$.

Jako badacz jestem zainteresowana zjawiskami edukacyjnymi w skali mikro, odkrywaniem znaczeń i wartości organizujących edukacyjny świat, poszukiwaniem warunków możliwości edukowania, nowych rozwiązań, sposobów bycia w edukacyjnej przestrzeni. Swoje rozważania osadzam więc $\mathrm{w}$ paradygmacie interpretatywistycznym ${ }^{12}$.

Opisane poniżej przemyślenia stanowią wynik studiowania między innymi literatury filozoficznej, pedagogicznej, jak również efekt analiz oraz interpretacji własnej tekstów kultury popularnej (rockowych oraz filmowych), analiz oraz interpretacji własnej prac studentów, esejów opowiadających o edukacyjnych sensach rockowych narracji. W niniejszym artykule przedstawiam tylko ogólne rezultaty tych działań, szczegółowa relacja z badań znajduje się natomiast w książce zaty tułowanej Edukacyjne konteksty rockowych narracji. Perspektywa teoretyczno-badawcza ${ }^{13}$. Tekst ma więc na celu zapoznanie Czytelnika z pewnym sposobem myślenia o kategorii spotkania z wybranymi pedagogicznymi konsekwencjami, jakie mogą mieć miejsce w wyniku spotkania młodych ludzi z tekstami kultury popularnej, między innymi z muzyką rockową, czy filmem, jak również ma na celu włączenie Odbiorcy w dyskusję nad zaprezentowanym zagadnieniem.

Publikację konstytuują trzy części. Pierwsza stanowi wprowadzenie $\mathrm{w}$ podjętą problematykę i traktuje o spotkaniu jako pedagogicznej kategorii, druga - koncentruje się wokół fenomenu spotkania z tekstami kultury popularnej, a dokładniej z rockowymi i filmowymi narracjami, natomiast w trzeciej, będącej podsumowaniem, opisuję spotkanie młodych ludzi z rockowymi narracjami, odwołując się do wyników badań własnych.

\section{Spotkanie jako kategoria pedagogiczna}

Spotkanie w literaturze pedagogicznej najczęściej odnosi się do szeroko rozumianego wychowania. Wychowanie ujmowane jako spotkanie ma swoje źródło w pedagogice humanistycznej, filozofii dialogu i spotkania między innymi M. Bubera, E. Levinasa, czy J. Tischnera, a jego ogólny sens można ująć jako „szczególny typ relacji z drugim człowiekiem”"14. Chodzi tutaj o „wszel-

${ }^{11}$ Z. Melosik, Kultura popularna i tożsamość młodzieży.

${ }^{12}$ K. Rubacha, Budowanie teorii pedagogicznych, [w:] Pedagogika. Podręcznik akademicki, red. Z. Kwieciński, B. Śliwerski, Warszawa 2005, s. 60-62.

${ }_{13}$ M. Adamska-Staroń, Edukacyjne konteksty rockowych narracji. Perspektywa teoretyczno-badawcza, Warszawa 2018.

${ }^{14}$ B. Śliwerski, Pedagogika ogólna. Podstawowe prawidłowości, Kraków 2012, s. 198. 
kie próby przełamywania struktury cogito podejmowane przez przedstawicieli pedagogiki hermeneutycznej, fenomenologicznej i dialektycznej"15. Studiując literaturę pedagogiczną, koncentrującą się wokół tego zagadnienia, można dostrzec, że najczęściej opisywane są dwa rodzaje spotkań: indeterministyczne oraz deterministyczne ${ }^{16}$. U podstaw takiego podziału leży ich struktura. W indeterministycznym podejściu rozwój osobowości uzależniony jest między innymi od losu. Spotkanie rozumiane jest tutaj jako przypadkowe zdarzenie $^{17}$. Przedstawiciele indeterministycznego stanowiska przekonują, że takich spotkań nie należy planować. Wszelka celowa działalność mogłaby pomniejszyć ich skutek, "usztywnić reakcje wobec innych i samego siebie”18. Z tej perspektywy spotkanie "może się wydarzyć w toku procesu edukacyjnego, nie może być jednak zaplanowanym działaniem czy sprytnie utajoną manipulacją"19. Wychowanie rozumiane jako spotkanie, osadzone $\mathrm{w}$ indeterministycznym podejściu nazywane jest „wychowaniem w toku spotkań” lub „wychowaniem w dialogu” ${ }^{20}$. Dialogu dwóch niezależnych osób, który „W swej istocie zakłada podwójność ról: mówienia i słuchania, dawania i brania, wychowania i samowychowania, kreuje to, co jest pomiędzy - wzajemne stwarzanie się dwóch podmiotów"21. Wychowanie splata się więc tutaj z samowychowaniem, zarówno wychowawcy, jak i wychowanka, i wychodzi poza obszar zwierzchnictwa i władzy, tym samym przestaje być jednokierunkowym oddziaływaniem ${ }^{22}$. W tym ujęciu wychowanie "nie jest czymś, co pedagog czyni drugiemu człowiekowi, ale czymś, co oboje czynią razem i czego wzajemnie doświadczają"23. Jest prawdziwym spotkaniem budowanym między innymi na takich wartościach, jak: szacunek, wolność, godność, autentyczność, zaangażowanie, zaufanie, odpowiedzialność za samego siebie oraz drugiego człowieka, empatia ${ }^{24}$. Spotkaniem, które jest czymś „,więcej niż

15 Tamże, s. 200.

16 Tamże.

17 Zob. tamże, s. 198; por. S. Kunowski, Podstawy współczesnej pedagogiki, Łódź 1981; R. Guardini, Koniec czasów nowożytnych. Świat i osoba. Wolność, łaska, los, przekł. Z. Włodkowa, M. Turowicz, J. Bronowicz, Kraków 1969.

18 B. Śliwerski, Pedagogika ogólna, s. 199.

19 Tamże, s. 200.

20 Tamże, s. 199-200.

21 Tamże, s. 200.

22 Tamże, s. 199.

23 Tamże.

${ }^{24}$ Empatia pojmowana jest tutaj jako coś więcej niż „wczuwanie się” w punkt widzenia drugiego człowieka. Chodzi tutaj o uznanie wyznania, że drugi człowiek/Inny/Ty „zawsze ma trochę racji”, co w konsekwencji powoduje zaakceptowanie kolejnego: „z pewnością ja nie całkiem mam rację". Takie deklaracje uczestników dialogu powodują, że dążą oni ku wspólnocie przeżyć, ku wspólnocie jednego spojrzenia na podjęte zagadnienia, sprawy, rzeczy - zob. J. Tischner, Inny. Eseje o spotkaniu, Kraków 2017. 
zwykłe zetknięcie się"25. Jego wyjątkowość polega na dostrzeżeniu niezwykłości, indywidualności spotykanego (wychowanka, wychowawcy) z całym jego dobrodziejstwem, z całym jego bagażem doświadczeń i przeżyć, polega na podejmowaniu próby wzajemnego zrozumienia. Taki wysiłek może pomóc konkretnej osobie, na przykład na nowo odkryć drugiego/innego wychowanka, wychowawcę - którego od dawna na co dzień spotyka, może zobaczyć go w innym świetle, w innej scenerii, z innej perspektywy. Dzięki temu uczestnicy spotkania wzajemnie się docierają, określają się $e^{26}$, przyjmują wobec siebie bezzałożeniową postawę, dzięki czemu mogą także doświadczać samych siebie. Tutaj stosunek wychowawczy zanika albo przeradza się w przyjaźńn ${ }^{27}$; „Ja" staje się poprzez spotkanie „Ty"28.

Wychowanie w przywołanym tutaj rozumieniu stanowi

ontyczne podłoże wymiany wartości, gdy przynajmniej jedna ze stron przepełniona troską o dobro drugiej, gotowa do działania na jej rzecz lub w związku z nią pozostaje $\mathrm{z}$ nią w relacji Ja-Ty. Wychowanek może nie być w stanie odwzajemnić wychowawcy swojej gotowości i zdolności do przyjęcia jego daru obecności i wpływu, realizacji proponowanych mu zadań czy współżycia w społeczności ${ }^{29}$.

Dla wychowawcy wejście $w$ tego typu wydarzenie stanowi wynik świadomego wyboru, świadomego zaangażowania się na rzecz drugiej osoby, prawdziwego z nią (współ)bycia, natomiast wychowanek jest na innym etapie rozwoju osobowego, jednak w podobny sposób odbiera postawę wychowawcy - „uświadamiając sobie, że istnieje we wspólnocie, słusznie odbiera ten fakt jako gwarancję troski, którą był, jest i będzie otoczony"30.

Drugie wspomniane przeze mnie stanowisko odnośnie do podjętego zagadnienia - wychowania jako spotkania - bazuje na deterministycznym ujęciu relacji międzyludzkich. Przedstawicielem oraz inicjatorem takiego podejścia w polskiej myśli filozoficznej XX wieku był Andrzej Nowicki - twórca nowej subdyscypliny badawczej: inkontrologii, inaczej nauki o spotkaniach, a dokładniej „,o formach, skutkach i programowaniu spotkań z ludźmi i ich dziełami"31. Zwraca się tutaj uwagę na skutki tych spotkań, które badane nie-

25 B. Śliwerski, Pedagogika ogólna, s. 199.

26 Tamże.

${ }_{27}$ M. Buber, Wychowanie, przekł. S. Grygiel, Znak, 1968, 4(166), s. 442-461 i 459; B. Śliwerski, Pedagogika ogólna, s. 201.

28 M. Buber, Wychowanie, s. 442-461 i 459.

29 B. Śliwerski, Pedagogika ogólna, s. 201.

30 W. Starnawski, Prawda jako zasada wychowania. Podstawy pedagogii personalistycznej w nawiazaniu do Karola Wojtyty - Jana Pawta II, Warszawa 2008, s. 410.

31 B. Śliwerski, Pedagogika ogólna, s. 202; zob. też A. Nowicki, O marksistowską inkontrologię. Zarys ogólnej teorii spotkań, Studia Filozoficzne, 1977, 5. 
jako od wewnątrz i od strony dającej się obiektywnie zweryfikować siły ich oddziaływania. Zachodzą one bowiem

w (...) w osobowości ucznia w rezultacie kontaktu z nauczycielami, a w szczególności te przypadki, kiedy spotkani nauczyciele przekształcają się - w procesie interioryzacji - w trwałe, podmiotowe składniki osobowości, tego, kto kiedyś był ich uczniem ${ }^{32}$.

Spotkania pomiędzy nauczycielami i uczniami, czy też wychowawcami a wychowankami, w tym ujęciu nie są wydarzeniami, które dzieją się tylko tu i teraz, ich „echa” mają miejsce również wiele lat później. Jednak tego typu spotkania analizowane są „od strony podmiotu wychowującego, osobowości już dojrzałej i refleksyjnie nastawionej na własną aktywność" 33 .

\section{Spotkanie z wybranymi tekstami kultury popularnej jako spotkanie z Innym}

W jaką przestrzeń wpisują się więc spotkania z tekstami kultury popularnej, na przykład z rockowymi czy też z filmowymi narracjami? Każde spotkanie z wybranym tekstem kulturowym jest indywidualne, wyjątkowe, osobiste. Jest tym rodzajem spotkania, które wydarza się w sposób naturalny, spontaniczny w życiu codziennym chyba każdego młodego człowieka, jak i tym rodzajem spotkania, które może wydarzyć się w toku procesu edukacyjnego. Kiedy już się wydarzy, może być realizowane w duchu idei dialogu. Chodzi tutaj o dialog, w którym tym "drugim”, tym „kimś”, jakimś „Ty”, który zaprasza do rozmowy, refleksji, do dyskusji wokół podjętych w danym tekście kwestii jest na przykład rockowa, czy filmowa narracja. Teksty te mogą stanowić odpowiedź na ważne dla ich odbiorców/uczestników takiego spotkania pytanie, które jest definicją istotnego dla nich problemu ${ }^{34}$. Podobnie więc jak w dialogu bezpośrednim. Tyle, że tutaj to odbiorca konkretnej narracji odtwarza to pytanie, na które dany tekst jest odpowiedzią ${ }^{35}$. $\mathrm{Na}$ tym właśnie polega różnica pomiędzy bezpośrednim dialogiem z drugim człowiekiem/innym a dialogiem z tekstem kulturowym. Rockowa czy filmowa narracja stanowi tutaj punkt odniesienia dla "Ja". To, co dzieje się w przestrzeni „pomiędzy” Ja - tekst kulturowy jest dobrodziejstwem spotkania z drugim człowiekiem poprzez jego dzieło, ale i z samym sobą, spotka-

32 A. Nowicki, Nauczyciele, Lublin 1981, s. 14; B. Śliwerski, Pedagogika ogólna s. 202.

33 B. Śliwerski, Pedagogika ogólna, s. 202-203.

34 Por. A. Folkierska, Kształcaca funkcja pytania. Perspektywa hermeneutyczna, [w:] Odmiany myślenia o edukacji, red. J. Rutkowiak, Kraków 1995; por. W. Jakubowski, Edukacja w świecie kultury popularnej, Kraków 2006, s. 130.

35 A. Folkierska, Ksztatcaca funkcja pytania. 
nia które pomaga w odkrywaniu i budowaniu własnej tożsamości, określonej jakości życia, które sprzyja w odkrywaniu rozmaitych wrażliwości, przeżyć, doświadczeń, refleksji, ale i przyjemności, które jest zgłębianiem wyobraźni własnej i drugiego człowieka. Wejście w relacje z rockowymi czy filmowymi tekstami jest więc spotkaniem człowieka z określonymi wartościami kultury, wzbogaceniem sposobów jego myślenia, rozumienia, przeżywania, (współ) działania, bycia w świecie, jest spotkaniem z innym.

Spotkanie z innym, bezpośrednie czy też pośrednio poprzez jego dzieła, realizujące się w duchu idei dialogu, staje się edukacyjną sytuacją, która sprzyja poznawaniu i rozumieniu samego siebie, innego, świata, otwieraniu się na odmienne poglądy, wartości, przekonania, która „wytwarza” przestrzeń między "Ja" $\mathrm{i}$ „Ty", sferę „pomiędzy”, a więc w miejsce, gdzie realizuje się człowiek ${ }^{36}$, gdzie odkrywa się inność.

Inny mieści w sobie paradoks: on jest inny niż ja, a jednak do mnie podobny - podobny w inności i inny w podobieństwie. (...) Inność innego wydobywa na jaw moją własną inność. Inność jest wzajemna. (...). Ciąg doświadczeń innego zamykają dwie granice: nigdy nie może dojść do tożsamości „nas” i nigdy nie może dojść do zupełnego zróżnicowania "między nami”. Zamknięta między tymi granicami „inność” jest dramatycznym ujawnieniem obustronnych tajemnic ${ }^{37}$.

W takim spotkaniu człowiek doświadcza drugiego człowieka, ale i samego siebie. Mamy do czynienia z wydarzeniem, podczas którego ujawnia się,

jak istotną rolę we wzajemnym naprzeciw siebie odgrywa to, co ci ludzie mają już za sobą ${ }^{38} \mathrm{i}$ ustanawia się nowy świat - świat spraw ważnych i nieważnych, chwil doniosłych i błahych, czasów świętych i czasów powszednich - słowem ustanawia hierarchię. Podejmując dialog z drugim, przychodzę ku niemu z wnętrza jakieś hierarchii; i drugi, podejmując dialog ze mną, przychodzi ku mnie z wnętrza hierarchii. Dialog tylko wtedy będzie owocny, gdy nasze hierarchie będą podobne lub gdy będą zdolne upodobnić się do siebie ${ }^{39}$.

Ważne jest, aby „wyjść ze swojej kryjówki”, wyjść poza swoje lęki, poza własną przestrzeń i znaleźć wspólną, czyli miejsce spotkania, miejsce rozmowy, początek jakiejś wspólnoty ${ }^{40}$. Taki dialog nie jest łatwy. Jest wymagający. Wiele przeszkód trzeba pokonać by go rozpocząć, potrzeba wydobyć wiele cierpliwości by go kontynuować, przezwyciężyć lęk i usunąć uprzedzenia, znaleźć wspólny język, słowa, które znaczą to samo ${ }^{41}$. Chodzi więc tutaj nie

\footnotetext{
${ }^{36}$ M. Buber, Ja i Ty. Wybór pism filozoficznych, s. 218.

37 J. Tischner, Inny, Znak, 2004, 1 (584).

38 J. Tischner, Filozofia dramatu, Kraków 2012, s. 17.

${ }^{39}$ Tamże, s. 17-18.

40 Por. tamże, s. 21.

${ }^{41}$ Tamże.
} 
tylko o relację Ja - Ty, ale również o „my”, o filozofię wspólnoty. Wspólne bycie razem, wspólne doświadczanie wydarza się jako współ - czasowość otwartych na siebie nawzajem osób, uczestników spotkania, Ja-Ty, staje się wyjątkową sytuacją nie pozostającą przecież bez znaczenia i dla teraźniejszości, i dla przyszłości, staje się sytuacją, która ujawnia otwartość człowieka na transcendencję, w ramach której dochodzi do wzajemnego obdarowywania się.

Muzyka rockowa, film - dzieła stworzone przez człowieka i dla człowieka - poprzez symbolizm, metaforę, alegorię zapraszają odbiorcę do dialogu w przywołanym powyżej rozumieniu. Dialogu, który rozbudza do (auto)refleksji, zachęca do spojrzenia na wybrane zagadnienie w szerszym kontekście, z różnych perspektyw, do samodzielnego, krytycznego myślenia. Rockowe, filmowe narracje, jeżeli człowiek da im szansę, pozytywnie się wobec nich nastroi ${ }^{42}$, wejdzie $\mathrm{z}$ nimi $\mathrm{w}$ relację, mogą stać się swoistym mediatorem pomiędzy przedstawicielami odmiennych kultur, „(...) pomiędzy kanonem kulturowym promowanym przez szkołę a kulturą popularną, czy pomiędzy subkulturami młodzieżowymi"43, mogą stać się prawdziwym spotkaniem, "dążeniem ku wspólnocie przeżyć i doznań z drugim człowiekiem, ku któremu zdąża" 44 , wzajemnym „obdarowywaniem” się. Człowiek doświadcza tego świata, który zostaje mu pokazany w takiej czy innej postaci. Doświadczenie to można ująć za pomocą takiej oto metafory:

Doświadczenie nie jest tylko widzeniem łąki, ale również radością z kwitnącej łąki, nie tylko widzeniem wody, ale również przyjemnością z zanurzenia ciała $\mathrm{w}$ wodzie, jest poczuciem swobody na szczycie góry, spokojem spływającym do duszy z obrazu rozgwieżdżonego nieba, a także lękiem w czasie burzy, chłodem w czasie mrozu, zmęczeniem po długiej wędrówce, bólem mięśni po ciężkiej pracy ${ }^{45}$.

Doświadczenie łączy się więc tutaj z zaangażowaniem, nastrojeniem, z podejmowaniem próby poznania i zrozumienia inności, przepracowania tego

42 By człowiek mógł prawdziwie spotkać się z jakimikolwiek tekstami kultury, np. rockowymi, czy filmowymi, to musi być a priori na nie wrażliwy. „Tę aprioryczną wrażliwość Heidegger nazywa nastrojeniem. Jest ona charakterystyką "przytomności« wobec świata - sposobem, w jaki otwiera się Dasein. Przytomność wobec świata jest zatem przytomnością wobec samego siebie - Dasein, wrażliwy na to, co może napotkać w świecie, jest zarazem wrażliwy na swoją wrażliwość, otwarty na swoją otwartość"; K. Michalski, Heidegger i filozofia wspótczesna, Warszawa 1978, s. 91; por. M. Heidegger, Bycie i czas, przekł. B. Baran, Warszawa 1994. Będąc w jakimś nastrojeniu człowiek rozpoznaje u siebie, że jest "pobudzony", "dotknięty", że obchodzi go to Naprzeciw, to "coś”, co jest w świecie. W nastrojeniu właśnie konstytuuje się otwarcie człowieka na świat, jest dokonywane, a nie przedstawiane - M. Adamska-Staroń, Człowiek w świecie kultury popularnej, [w:] Kultura popularna, s. 31-42.

${ }^{43}$ T. Szkudlarek, Pedagogika krytyczna, [w:] Pedagogika. Podręcznik akademicki, red. Z. Kwieciński, B. Śliwerski, Warszawa 2005, s. 373.

${ }^{44}$ A. Sztylka, Jak stawać się humanista? Warszawa 1999, s. 54.

${ }^{45} \mathrm{~J}$. Tischner, Inny. Eseje o spotkaniu, s. 15. 
wszystkiego co wypełnia poznawany świat, czy też używając terminologii J. Tischnera - „przetrawienia”. Nie wszystko można „przetrawić” zauważa:

Część przeżyć z góry wykluczamy, spychamy poniżej progu świadomości, inne wyolbrzymiamy, przeinaczamy, by uczynić je bardziej „strawnymi” dla siebie. W tym przejawia się indywidualność innego, że ma on własny sposób „sposób trawienia” świata ${ }^{46}$,

nazywany przez J. Tischnera „indywidualnym skrętem świadomości” ${ }^{47}$. To właśnie uchwycenie człowieka w jego indywidualnym skręcie, który pokazuje jego niepowtarzalność, jego osobisty sposób przeżywania życia, można nazwać poznaniem „innego jako innego i zarazem nie-innego" ${ }^{48}$, dzięki czemu można dowiedzieć się "z grubsza - co inny »trawi«, a czego »nie trawi«"49. Pedagogiczna konsekwencja zaangażowania się w tego typu bycie w świecie ujawnia się więc w zainteresowaniu nie tylko samym sobą, ale i drugim człowiekiem, innym, w podejmowaniu prób/y jego poznania (poznania jego trosk, niepokojów, lęków, jego potencjału, pasji, talentów, zdolności), w dążeniu do wzajemnego zrozumienia, w gotowości do uznania, że Ty "zawsze ma trochę racji”, jak również w weryfikacji własnej postawy wobec samego siebie, wobec drugiego człowieka i jego dzieł, innych istot żywych, wobec inności, w weryfikacji tekstów, w które on sam się zanurza (np. rockowych, czy filmowych), w „wyjściu ze swojej kryjówki”. Popularyzowanie/promowanie/ realizowanie/ „uprawianie” takiego bycia w świecie, tym samym w świecie edukacji, może przyczynić się również do zminimalizowania tendencji do konsumpcyjnego bycia, obniżenia chęci głównie posiadania, zminimalizowania tendencji do instrumentalizacji ludzkich relacji, czy tak popularnego nie tylko w świecie młodych ludzi "hejtowania” - będącego obecnie bardzo dużym problemem, zjawiskiem rozwijającym się na ogromną skalę.

\section{Spotkanie z rockowymi narracjami. Kilka uwag podsumowania z badań własnych}

Kultura popularna, szczególnie muzyka rockowa czy film, jest i była przedmiotem rozmaitych teoretycznych rozpraw, badań naukowych ${ }^{50}$. Roc-

46 Tamże, s. 16.

47 Tamże.

48 Tamże, s. 17.

49 Tamże.

50 Zob. m.in.: Z. Melosik, Kultura popularna i tożsamość młodzieży; tenże, Postmodernistyczne kontrowersje wokót edukacji, Toruń - Poznań 1995; tenże, Rap, walka o znaczenia i pedagogika, Kultura Współczesna, 1996, 1-2; tenże, Pedagogika kultury popularnej, [w:] Pedagogika. Podręcznik akademicki; W. Jakubowski, Edukacja w dobie kultury popularnej; T. Szkudlarek, Z. Melosik, Kultu- 
kowy, czy filmowy świat to codzienna przestrzeń, szczególnie dla młodego człowieka, przestrzeń określonych ideałów, określonej filozofii życia, stanowiąca , akt kreowania wspólnoty" ${ }^{51}$, ważne - zwłaszcza dla dzieci i młodzieży - kryterium tożsamości ${ }^{52}$. Świat, który wart jest uwagi badacza, a szczególnie pedagoga. To świat również i moich naukowych zainteresowań. Na przestrzeni ostatnich dziesięciu lat realizowałam badania, które koncentrowały się wokół edukacyjnych kontekstów rockowych narracji. Głównym celem badań uczyniłam poznanie, zrozumienie, opis edukacyjnych sensów nadanych przez studentów pedagogiki Akademii im. Jana Długosza w Częstochowie rockowym narracjom oraz poznanie, zrozumienie, opis edukacyjnych sensów nadanych przez twórców rocka rockowym oraz innym artystycznym tekstom. $\mathrm{W}$ związku z tak obranym celem poszukiwałam odpowiedzi na następujące pytanie: Jakie edukacyjne sensy można nadać rockowym narracjom? (główny

ra, tożsamość i edukacja. Migotanie znaczeń, Kraków 1998; W. Siwak, Hastowe pragnienia w tekście utworu rockowego, [w:] Estetyka pragnień, red. J. Brach-Czainy, Lublin 1988; tenże, Estetyka rocka, Warszawa 1993; J. Werenstein-Żuławski, M. Pęczak, Tekst piosenki rockowej, [w:] Spontaniczna kultura młodzieżowa. Wybrane zjawiska, red. M. Pęczak, J. Wertenstein-Żuławski, Wrocław 1991; J. Werenstein-Żuławski, To tylko rock'n'roll, Warszawa 1990; tenże, Między rozpacza a nadzieją. Rock, młodzież, społeczeństwo, Warszawa 1993; A. Dorobek, Rock - problemy, sylwetki, konteksty (szkice z estetyki i socjologii rocka), Bydgoszcz 2001; W. Królikowski, Mowa wzmacniaczy. Definicja i treść utworu rockowego, Jazz, 1982, 4, s. 10-11; M. Michalak, Muzyka rockowa w świadomości i edukacji młodzieży gimnazjalnej, Toruń 2011; J. Burszta, M. Rychlewski (red.), A po co nam rock. Między dusza a ciatem, Warszawa 2003; M. Rychlewski, Rewolucja rocka. Semiotyczne wymiary elektrycznej ekstazy, Gdańsk 2011; A. Gromkowska-Melosik (red.), Kultura popularna i (re)konstrukcje tożsamości, Poznań 2007; B. Hoffmann, Rock a przemiany kulturowe końca XX wiek, Warszawa 2001; W. Jakubowski, S. Jaskulska (red.), Kultura mediów, ciało i tożsamość - konteksty socjalizacyjne i edukacyjne, Kraków 2011; D. Hejwosz, W. Jakubowski (red.), Kultura popularna - tożsamość - edukacja, Kraków 2010; A. Cybal-Michalska, P. Wierzba (red.), Dyskursy kultury popularnej; A. Idzikowska-Czubaj, Funkcje kulturowe i historyczne znaczenie polskiego rocka, Poznań, 2006; taże, Rock w PRL-u. O paradoksach wspótistnienia, Poznań 2011; A.C. North, D.J. Hargreaves, S.A. O'Neill, The importance of music to adolescents, The British Journal of Educational Psychology, 2010, 70, 2, s. 255-272; S. Saarikallio, J. Erkkilä, The role of music in adolescents' mood regulation, Psychology of Music, 2007, 35, 1, s. 88-109; P.M. Greenfield i in., What is Rock Music Doing to the Minds of our Youth? A First Experimental Look at the Effects of Rock Music Lyrics and Music Videos, The Journal of Early Adolescence (JEA), 1987, 7, 3, s. 315-329; S. Villani, Impact of Media on Children and Adolescents: A 10-Year Review of the Research, Journal of the American Academy of Child and Adolescent Psychiatry, 1998, 40, 4, s. 392-401; P.S. Campbell, Of Garage Bands and Song-getting: The Musical Development of Young Rock Musicians, Research Studies in Music Education, 1995, 4, 1, s. 12-20; E. Macan, Progresywny urock, przekł. M. Majchrzak, Torun 2001; J. Curtis, Rock Eras: Interpretations of Music and Society, 1954-1984, Ohio 1987; A. Moor, Rock: The primary Text; Developing a Musicology of Rock, Buckingham 1993; S. Frith, Sound Effects: Youth, Leisure and the Politics of Rock \& Roll, New York 1981, London 1983; J. Stuessy, S.D. Lipscomb, Rock and Roll: Its History and Stylistic Development, New Jersey 2002; C. Cutler, O muzyce popularnej. Pisma teoretyczno-krytyczne, przekł. I. Socha, Kraków 1999.

51 J. Storey, Studia kulturowe i badanie kultury popularnej. Teorie i metody, przekł. J. Barański, Kraków 2003, s. 97.

${ }^{52}$ Z. Melosik, Kultura popularna i tożsamość młodzieży. 
problem badawczy). Problem główny wyznaczył mi problemy szczegółowe, między innymi: Jakie edukacyjne sensy nadali rockowym narracjom studenci pedagogiki Akademii im. Jana Długosza w Częstochowie? Przeprowadzone przeze mnie badania, analizy oraz interpretacje zgromadzonego materiału badawczego $^{53}$ - esejów studentów, na temat edukacyjnych sensów rockowych narracji oraz wywiadów z twórcami rocka, koncentrujących się również wokół edukacyjnych sensów rockowych oraz innych artystycznych narracji, pozwoliły mi zrealizować cel główny, tym samym pozwoliły udzielić odpowiedzi na wszystkie postawione przeze mnie pytania badawcze. Szczegółowo relacją z badań, wnioskami dzielę się we wspomnianej już książce Edukacyjne konteksty rockowych narracji. Perspektywa teoretyczno-badawcza. W tym miejscu odwołam się tylko do kwestii dotyczącej edukacyjnych sensów, jakie nadali rockowym narracjom badani - studenci Akademii im. Jana Długosza w Częstochowie.

Analiza oraz interpretacja zgromadzonego materiału pozwoliła zauważyć, że badani uznali przestrzeń rockowych narracji za przestrzeń o edukacyjnych sensach. Punktem wyjścia do ich określenia czynili konkretną definicję edukacji. Najczęściej wybierane były definicje autorstwa B. Śliwerskiego, W. Okonia, K. Rubachy, Z. Kwiecińskiego. W konsekwencji edukacyjne sensy nadawali tym rockowym treściom, które sprzyjają zdobywaniu nowych wiadomości o świecie, drugim człowieku, innej kulturze, które uruchamiają chęć do ich pogłębiania i aktualizowania, zachęcają do stawiania różnego rodzaju pytań, inspirują do aplikowania zdobytych wiadomości $\mathrm{w}$ praktycznym działaniu, zapraszają do relacyjnego uczestnictwa w kulturze, do współpracy z drugim człowiekiem, jak również tym treściom, które wyzwalają akty osobistej ekspresji, potrzebę pracy nad samym sobą, poznawania i rozumienia samego siebie, potrzebę samorealizacji, które sprzyjają także wyrażaniu tłumionych emocji, powodują przekuwanie negatywnej energii $\mathrm{w}$ pozytywną moc, pozwalają zaspokoić $\mathrm{w}$ bezpieczny sposób potrzeby emocjonalne, oderwać się od rzeczywistości, jak również powodują stan ogólnego zadowolenia. A zatem, edukacyjne sensy nadawali tym treściom, które ich zdaniem wpisywały się w semantyczną przestrzeń wybranych przez siebie definicji edukacji. Najwięcej edukacyjnych sensów nadawanych było tekstom, które rozbudzały do autorefleksji, poznawania samego siebie, pracy nad samym sobą, samorealizacji, samodoskonalenia się. Rockowe narracje, jak sami podkreślali, pozwalają przyjrzeć się swojej egzystencji, sprzyjają zadumie nad swoim życiem, nad swoją postawą wobec samego siebie, ale również wobec drugiego człowieka, wobec innych

${ }^{53}$ Materiał badawczy uzyskałam za pomocą dwóch metod badawczych: metody hermeneutycznej oraz pogłębionego wywiadu jakościowego skoncentrowanego na problemie. 
istot żywych, wobec Boga, czy wobec świata, uruchamiają różnego rodzaju pytania natury egzystencjalnej, biograficznej, typu: „Kim jestem?”, ,Jaką drogą chcę podążać?", "Jakie realizować wartości?”, „W jaki sposób mogę poznawać siebie, doskonalić swoje życie?”, czy "Jak radzić sobie ze swoimi słabościami?". Rockowe narracje jawią się również jako ogniwo kulturowej integracji, pole wspólnych przeżyć i doznań, dostarczają wzorów postępowania, pomagają w otwieraniu się na dialog, dostrzeganiu i szanowaniu różnic kulturowych, jednocześnie rozbudzają do krytycznego, samodzielnego myślenia. Edukujący - zdaniem badanych - może być praktycznie każdy kulturowy tekst, to odbiorca o tym decyduje,

możemy upowszechniać swoistą praktykę edukacyjną poprzez niemal każdą aktywność. Należy tylko wyrazić chęć do zdobycia nowej wiedzy, umiejętności, zmiany postaw czy też do rozwoju własnej osobowości. Zaangażowanie może być „furtką" do tego, by do naszego umysłu dotarł wartościowy przekaz ${ }^{54}$.

Badani opowiedzieli o efektach własnych spotkań z rockowymi tekstami, opisali do czego one inspirują, jakie działania podejmują pod ich wpływem, co dzięki nim zyskują. Uczestnictwo w tej rockowej przestrzeni nie jest dla nich bezrefleksyjne, nie jest li tylko estetycznym doznaniem. Rockowe narracje są według nich godne uwagi, przenikania, odkrywania, uczestnictwa nie tylko ze względów estetycznych, rozrywkowych, ale również ze względu na edukacyjne siły, jakie mają. Spotkanie z rockowymi narracjami oznacza dla przyszłych pedagogów - studentów pedagogiki AJD - możliwość myślenia "po swojemu", przekroczenie granic własnego, indywidualnego, intymnego świata, otworzenie się między innymi na nowe sytuacje, nowe doświadczenia, na drugiego człowieka. Przekroczenie tych granic, wyjście poza własne Ja, łączy się w ich przekonaniu z pogłębianiem swojego życia osobowego, ale także ze spojrzeniem na siebie z perspektywy drugiego człowieka, innej kultury $^{55}$. Dlatego też sami zachęcają do wykorzystywania rockowych oraz innych artystycznych narracji (np. filmu, malarstwa, fotografii) w edukacji. Podkreślają, że proces zdobywania wiedzy nie musi realizować się tylko w ramach szkoły, instytucjonalnie, że „może być podejmowany samorzutnie, między innymi przez słuchanie muzyki, która zawiera odpowiednią treśćn" 56 . Nie wszystkie rockowe teksty, zdaniem badanych, mogą kierować w dobrą stronę, „nie wszystkim - zauważają - zależy, by świat był piękny.

${ }^{54}$ Katarzyna Wróblewska studentka pedagogiki Akademii im. Jana Długosza w Częstochowie, realizacja 1, s. 180.

${ }^{55}$ E. Mounier, Wprowadzenie do egzystencjalizmów, Kraków1964; por. E. Biłos, Ku nauczaniu personalistycznemu, Częstochowia 2000, s. 25.

${ }^{56}$ Sergiusz, Artur, Sebastian, Maciej, Pełne dane osobowe Autorów eseju dostępne są w moim archiwum. 
Poprzez swoje utwory mogą manipulować swoimi odbiorcami, zachęcać do czynienia rzeczy, które niekoniecznie mają pozytywną energię" ${ }^{\prime \prime 7}$. To, co może uchronić młodzież przed negatywnymi konsekwencjami, takiej „manipulacyjnej" działalności, zauważają, to prawdziwe spotkanie z drugim człowiekiem, $\mathrm{z}$ jego dziełami, realizujące się $\mathrm{w}$ duchu idei dialogu, świadome, rozumiejące uczestnictwo $\mathrm{w}$ tej kulturowej przestrzeni, to zainteresowanie dorosłych - rodziców, nauczycieli, pedagogów - „światem własnych dzieci, uczniów, wychowanków", ich pasjami, zainteresowaniami, codziennością, to „uczynić świat muzyki, w którym funkcjonują ich podopieczni, punktem wyjścia do ich zrozumienia, sprawić, aby słuchanie muzyki było nie tylko rozrywką, ale również sposobem rozbudzającym refleksję nad samym sobą i rzeczywistością, w której funkcjonują, tym samym i nad treścią, piosenek, których słuchają" ${ }^{58}$. Studenci pokazali więc tę "pozaestetyczną" jakośćs9 rockowego świata, najbardziej interesującą dla pedagoga, świata który stanowi "potężny czynnik edukacji i socjalizacji"60. Pokazali, że rockowa przestrzeń nie musi być postrzegana ,jako obszar, w którym bezmyślne masy manipulowane są przez elektroniczne media" ${ }^{\prime 61}$, że nie musi być uznawana za tę "gorszą", że może być pomyślana jako zwyczajnie inny fragment kulturowego świata ${ }^{62}$, w ramach którego może dojść do „wyzwolenia się z »więzienia tożsamości« skonstruowanej $w$ trakcie »przesocjalizowania« jednostki $\mathrm{w}$ jednoznacznie określoną matrycę. $\mathrm{Z}$ kolei uwolnienie się od pułapki narzuconych sposobów postrzegania i pojmowania świata sprawia, że człowiek może sam tworzyć świat, w którym żyje. I tylko przyjmując takie zmierzające do upodmiotowienia młodzieży stanowisko, możemy stać się jej partnerem i częścią rzeczywistości, w której żyje i którą akceptuje"63. Pedagog, nauczyciel, wychowawca, czy rodzic, zachęcając swoich uczniów/studentów/wychowanków/swoje dzieci do relacyjnego bycia w świecie, $w$ tym do relacyjnego bycia w świecie kultury popularnej, na przykład w świecie rockowych czy filmowych narracji, traktuje ich nie jako produkt społecznych procesów czy stosunków interpersonalnych, ale jako osobę autonomiczną ${ }^{64}$, zdolną do przekraczania własnego Ja, pogłębiania swojego życia osobowego „ku gó-

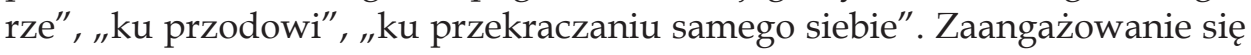
w odkrywanie i rozumienie samego siebie łączy się tutaj z postawą „oddania

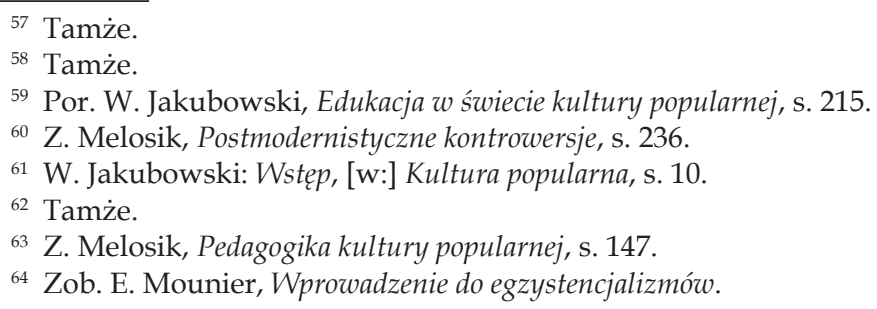


się do dyspozycji drugiego", „dążenia ku drugiemu człowiekowi/innemu”, „ku wspólnocie” 65 .

Wypowiedzi badanych stanowią więc nie tylko źródło poznania i rozumienia ich sposobów myślenia o edukacji (bądź jej fragmentach), źródło poznania i rozumienia edukacyjnych sensów, jakie nadali oni rockowym narracjom, ale również stanowią źródło poznania świata, w którym oni uczestniczą. Dzięki realizowaniu się takiej właśnie pedagogii studenci pedagogiki mają możliwość dostrzegania idei, myśli, przekonań konstytuujących pedagogiczne koncepcje, ideologie wychowania czy paradygmaty poza akademickimi salami, w pozainstytucjonalnej przestrzeni. Dzięki temu przyszli pedagodzy „mają szansę być współtwórcami, a nie jedynie konsumentami wiedzy pedagogicznej" ${ }^{66}$. Szkoda więc, że rockowe narracje są traktowane przez niektórych pedagogów, rodziców, opiekunów jako „estetyczny Inny”, "gorszy Inny". Negatywne wobec niej nastrojenie powoduje, że nie dostrzega się w niej tych edukacyjnych sensów, jakie zauważa/odbiera/docenia/nadaje młodzież tej inspiracji do działania na rzecz własnego rozwoju, poznania i rozumienia samego siebie, świata, drugiego człowieka. Warto poznawać świat, w którym na co dzień uczestniczy młode pokolenie, warto poznawać to, co w tych kulturowych tekstach dostrzega, jak je odczytuje, jakie sensy i znaczenia im nadaje. Warto zobaczyć w tych rockowych czy innych artystycznych tekstach siłę, która motywuje, inspiruje, edukuje, uznać je za takiego innego, który jak ten artysta otwiera oczy i uszy tym, którzy „mają oczy ku widzeniu, a nie widzą, i mają uszy ku słyszeniu, a nie słyszą"67, bez którego "głodni - nic, tylko chleba by szukali. Zmęczeni - czekaliby, kiedy usną, kiedy odpoczną. I zawsze byliby w strachu, zawsze w pośpiechu i zawsze byliby tam, gdzie nie trzeba. Artysta każe ludziom przystanąć, zadziwić się światu, zadumać, zachwycić, zapłakać nad cudzym nieszczęściem, uradować się cudzym szczęściem, myśleć nie tylko o sobie"68.

\section{BIBLIOGRAFIA}

Adamska-Staroń M., Edukacyjne konteksty rockowych narracji. Perspektywa teoretyczno-badawcza, Wydawnictwo Difin, Warszawa 2018.

Adamska-Staroń M., Spotkanie z Innym w perspektywie idei dialogu, Pedagogika XXIII. Prace Naukowe Akademii im. Jana Długosza, 2014, XXIII.

Biłos E., Ku nauczaniu personalistycznemu, Wydawnictwo Wyższej Szkoły Pedagogicznej w Częstochowie, 2000.

${ }^{65}$ Tamże; por. E. Biłos, Ku nauczaniu personalistycznemu, s. 25.

${ }^{66}$ B. Łukasik, M. Adamska-Staroń, Twórczy potencjał edukacyjnych spotkań akademickich, Pedagogika XXIV. Prace Naukowe Akademii im. Jana Długosza, 2015, XXIII, s. 177.

${ }^{67}$ J. Tischner, Boski mlyn, Kraków 1992, s. 30-31.

${ }^{68}$ Tamże. 
Bruner J., Życie jako narracja, Kwartalnik Pedagogiczny, 1990, 4(138).

Buber M., Ja $i$ Ty. Wybór pism filozoficznych, przekł. J. Doktór, Instytut Wydawniczy PAX, Warszawa 1992.

Buber M., Wychowanie, przekł. S. Grygiel, Wydawnictwo Znak, 1968, 4(166).

Burszta W., Kultura popularna jako wspólnota uczuciowa, Kultura Popularna, 2002, 0.

Burszta J., Rychlewski M. (red.), A po co nam rock. Między dusza a ciałem, Wydawnictwo Książkowe Twój Styl, Warszawa 2003.

Campbell P.S., Of Garage Bands and Song-getting: The Musical Development of Young Rock Musicians, Research Studies in Music Education, 1995, 4, 1.

Curtis J., Rock Eras: Interpretations of Music and Society, 1954-1984, Bowling Green State University Popular Press, Ohio 1987.

Cutler C., O muzyce popularnej. Pisma teoretyczno-krytyczne, przekł. I. Socha, Wydawnictwo Zielona Sowa, Kraków 1999.

Cybal-Michalska A., Wierzba P. (red.), Dyskursy kultury popularnej w społeczeństwie wspótczesnym, Oficyna Wydawnicza Impuls, Kraków 2012.

Derbis R., Dlaczego zajmujemy się jakością życia, [w:] Psychologiczne konteksty jakości życia społecznego, red. R. Derbis, Wydawnictwo Akademii im. Jana Długosza w Częstochowie, Częstochowa 2010.

Dołęga Z., Samotność młodzieży - analiza teoretyczna i studia empiryczne, Wydawnictwo Uniwersytetu Śląskiego, Katowice 2003.

Dorobek A., Rock - problemy, sylwetki, konteksty (szkice z estetyki i socjologii rocka), Instytut Wydawniczy Świadectwo, Bydgoszcz 2001.

Dudziuk M., Szczepańska S., Filmowanie jest filozofowaniem, Melee, 2009, 5.

Folkierska A., Ksztatcaca funkcja pytania. Perspektywa hermeneutyczna, [w:] Odmiany myślenia o edukacji, red. J. Rutkowiak, Oficyna Wydawnicza Impuls, Kraków 1995.

Frith S., Sound Effects: Youth, Leisure and the Politics of RockERoll, Pantheon Books, New York 1981, London 1983.

Greenfield P.M., Bruzzone L., Koyamatsu K., Satuloff W., Nixon K., Brodie M., Kingsdale D., What is Rock Music Doing to the Minds of our Youth? A First Experimental Look at the Effects of Rock Music Lyrics and Music Videos, The Journal of Early Adolescence (JEA), 1987, 7, 3.

Gromkowska-Melosik A. (red.), Kultura popularna i (re)konstrukcje tożsamości, Wydawnictwo Wyższej Szkoły Humanistycznej w Lesznie, Poznań 2007.

Gromkowska-Melosik A., Edukacja i nierówność spoteczna kobiet. Studium dynamiki dostępu, Oficyna Wydawnicza Impuls, Kraków 2011.

Gromkowska-Melosik A., Elitarne szkolnictwo średnie. Między reprodukcją społeczno-kulturowa a ruchliwością konkurencyjna, Wydawnictwo Naukowe UAM, Poznań 2015.

Guardini R., Koniec czasów nowożytnych. Świat i osoba. Wolność, łaska, los, przekł. Z. Włodkowa, M. Turowicz, J. Bronowicz, Wydawnictwo Znak, Kraków 1969.

Heidegger M., Bycie i czas, przekł. B. Baran, Wydawnictwo Naukowe PWN, Warszawa 1994.

Hejwosz D., Jakubowski W. (red.), Kultura popularna - Tożsamość - Edukacja, Oficyna Wydawnicza Impuls, Kraków 2010.

Hoffmann B., Rock a przemiany kulturowe końca XX wiek, Semper, Warszawa 2001.

Idzikowska-Czubaj A., Funkcje kulturowe i historyczne znaczenie polskiego rocka, Wydawnictwo Poznańskie, Poznań 2006.

Idzikowska-Czubaj A., Rock w PRL-u. O paradoksach wspótistnienia, Wydawnictwo Poznańskie, Poznań 2011.

Jakubowski W., Edukacja w dobie kultury popularnej, Oficyna Wydawnicza Impuls, Kraków 2006. 
Jakubowski W., Wstęp, [w:] Kultura popularna - Tożsamość - Edukacja, red. D. Hejwosz, W. Jakubowski, Oficyna Wydawnicza Impuls, Kraków 2010.

Jakubowski W., Jaskulska S. (red.), Kultura mediów, ciało i tożsamość - konteksty socjalizacyjne i edukacyjne, Oficyna Wydawnicza Impuls, Kraków 2011.

Kowalik S., Jakość życia psychicznego, [w:] Jakość rozwoju a jakość życia, red. R. Derbis, Wydawnictwo WSP w Częstochowie, Częstochowa 2000

Kowalik S., Temporalne uwarunkowania jakości życia, [w:] Psychologiczne i pedagogiczne wymiary jakości życia, red. A. Bańka, R. Derbis, Wydawnictwo Naukowe UAM, Poznań 1994.

Królikowski W., Mowa wzmacniaczy. Definicja i treść utworu rockowego, Jazz, 1982, 4.

Kunowski S., Podstawy wspótczesnej pedagogiki, Wydawnictwo Salezjańskie, Łódź 1981.

Lodder G., Goossens L., Scholte R., Verhagen M., Adolescent Loneliness and Social Skills: Agreement and Discrepancies Between Self-, Meta-, and Peer-Evaluations, Journal of Youth and Adolescence, 1998, 45(12).

Luhmann M., Hawkley L., Age Differences in Loneliness From Late Adolescence to Oldest Old Age, Developmental Psychology, 2016, 50(6).

Łukasik B., Adamska-Staroń M., Twórczy potencjał edukacyjnych spotkań akademickich, Pedagogika XXIV. Prace Naukowe Akademia im. Jana Długosza, 2015, XXIII.

Macan E., Progresywny urock, przekł. M. Majchrzak, C \& T, Torun 2001.

Maes M., Van den Noortgate W., Vanhalst J., Beyers W., Goossens L., The Children's Loneliness Scale Factor - Structure and Construct Validity in Belgian Children, Assessment, 2015, 24(2).

Melosik Z., Rap, walka o znaczenia i pedagogika, Kultura Współczesna, 1996, 1-2.

Melosik Z., Pedagogika kultury popularnej, [w:] Pedagogika. Podręcznik akademicki. Subdyscypliny i dziedziny wiedzy o edukacji, red. B. Śliwerski, Gdańskie Wydawnictwo Psychologiczne, Gdańsk 2010.

Melosik Z., Kultura popularna i tożsamość młodzieży. W niewoli władzy i wolności, Oficyna Wydawnicza Impuls, Kraków 2013.

Michalak M., Muzyka rockowa w świadomości i edukacji młodzieży gimnazjalnej, Wydawnictwo Adam Marszałek, Toruń 2011.

Michalski K., Heidegger i filozofia wspótczesna, Państwowy Instytut Wydawniczy, Warszawa 1978.

Moor A., Rock: The primary Text; Developing A Musicology Of Rock, Open University Press, Buckingham 1993.

Mounier E., Wprowadzenie do egzystencjalizmów, Wydawnictwo Znak, Kraków1964.

Nalaskowski A., Edukacja. Korzenie, źródła, narracje, Oficyna Wydawnicza Impuls, Kraków 2017.

Nalaskowski A., Widnokręgi edukacji, Oficyna Wydawnicza Impuls, Kraków 2002.

North A.C., Hargreaves D.J., O'Neill S.A., The importance of music to adolescents, The British Journal of Educational Psychology, 2010, 70, 2.

Nowak S., Kultura popularna, czyli twórcza niesubordynacja, MOCAK Forum, 2012, 1(3).

Nowak-Dziemianowicz M., Narracyjne możliwości pedagogiki a kryzys kultury i wychowania, http://forumoswiatowe.pl/index.php/czasopismo/article/view/, [dostęp: 12.11. 2018].

Nowicki A., O marksistowską inkontrologię. Zarys ogólnej teorii spotkań, Studia Filozoficzne, 1977, 5.

Nowicki A., Nauczyciele, Wydawnictwo Lubelskie, Lublin 1981.

Postmodernistyczne kontrowersje wokót edukacji, Edytor, Torun - Poznań 1995.

Rubacha K., Budowanie teorii pedagogicznych, [w:] Pedagogika. Podręcznik akademicki, red. Z. Kwieciński, B. Śliwerski, Wydawnictwo Naukowe PWN, Warszawa 2005. 
Russo F., Toksyczna samotność, Świat Nauki, 2018, 3(19).

Rychlewski M., Rewolucja rocka. Semiotyczne wymiary elektrycznej ekstazy, Oficynka, Gdańsk 2011.

Saarikallio, Erkkilä J., The role of music in adolescents' mood regulation, Psychology of Music, 2007, 35, 1.

Siwak W., Hastowe pragnienia w tekście utworu rockowego, [w:] Estetyka pragnień, red. J. BrachCzainy, Lublin 1988.

Siwak W., Estetyka rocka, Samper, Warszawa 1993.

Starnawski W., Prawda jako zasada wychowania. Podstawy pedagogii personalistycznej w nawiazaniu do Karola Wojtyty - Jana Pawła II, Wydawnictwo UKSW, Warszawa 2008.

Storey J., Studia kulturowe i badanie kultury popularnej. Teorie i metody, przekł. J. Barański, Wydawnictwo UJ, Kraków 2003.

Strykowski W., Skrzydlewski W. (red.), Media i edukacja w dobie integracji, Wydawnictwo eMPi2, Poznań 2002.

Stuessy J., Lipscomb S.D., Rock and Roll: Its History and Stylistic Development, Prentice Hall, New Jersey 2002.

Szkudlarek T., Pedagogika krytyczna, [w:] Pedagogika. Podręcznik akademicki, red. Z. Kwieciński, B. Śliwerski, Wydawnictwo Naukowe PWN, Warszawa 2005.

Szkudlarek T., Melosik Z., Kultura, tożsamość i edukacja. Migotanie znaczeń, Oficyna Wydawnicza Impuls, Kraków 1998.

Sztylka A., Jak stawać się humanistą? Wydawnictwo Instytutu Technologii Eksploatacji, Warszawa 1999.

Śliwerski B., Pedagogika ogólna. Podstawowe prawidłowości, Oficyna Wydawnicza Impuls, Kraków 2012.

Tischner J., Boski młyn, Oficyna Podhalańska: Secesja, Kraków 1992.

Tischner J., Inny, Znak, 2004, 1(584).

Tischner J., Filozofia dramatu, Wydawnictwo Znak, Kraków 2012.

Tischner J., Inny. Eseje o spotkaniu, Wydawnictwo Znak, Kraków 2017.

Victor Ch., Yang K., The Prevalence of Loneliness Among Adults: A Case Study of the United Kingdom, The Journal of Psychology, 2011, 146 (1-2).

Villani S., Impact of Media on Children and Adolescents: A 10-Year Review of the Research, Journal of the American Academy of Child and Adolescent Psychiatry, 1998, 40, 4.

Wasilewska-Ostrowska K., Młodzież wobec samotności w świetle badań porównawczych, Kultura i Wychowanie, 2014, 8(2).

Werenstein-Żuławski J., Między rozpacza a nadzieją. Rock, młodzież, społeczeństwo, Instytut Kultury, Warszawa 1993.

Werenstein-Żuławski J., To tylko rock'n'roll, Związek Główny Autorów i Kompozytorów ZAKR, Warszawa 1990.

Werenstein-Żuławski J., Pęczak M., Tekst piosenki rockowej, [w:] Spontaniczna kultura młodzieżowa. Wybrane zjawiska, red. M. Pęczak, J. Wertenstein-Żuławski, WOK, Wrocław 1991. 